\title{
DETERMINING THE WEIGHTS OF MARKETING MIX COMPONENTS USING ANALYTIC NETWORK PROCESS
}

\author{
Şenay Sadıç* \\ Industrial Engineering Department \\ Istanbul Technical University \\ Istanbul, TURKEY \\ E-mail: $\underline{\text { sadic@itu.edu.tr }}$
}

\begin{abstract}
Marketing Mix (4P); composed of Product, Price, Promotion and Place; is a set of tools that should be coherently designated to achieve a company's goals. In order to create brand equity and customer loyalty, any manufacturing or service company should manage and shape product, place, price and promotion strategies. To create competitive advantage, the relationships between the components of Marketing Mix should be analyzed in detail, and the weights of its subcomponents are needs to be determined. The weights of components will further be used in selecting optimal marketing mix. To solve this problem, an Analytic Network approach will be proposed in this paper, and the product mix components and their sub groups will be ranked according to their weights.
\end{abstract}

Keywords: Marketing Mix, Analytic Network Process, Decision Making.

\section{Introduction}

In today's world, the importance of marketing accrues rapidly because of the rough market conditions. Companies need to find the best way to access the customers and make sure that they are satisfied with their own products and services. The companies' way of serving their product directly affects the companies' market performance and it leads to financial success or failure (2009, Chen, H., Green, R.D.).

Developing an integrated marketing plan and generating a successful marketing mix is a complex process that requires a deep understanding of many factors. Even though marketing mix accounts for the formulation of a company's core marketing decisions, it fails to provide a well defined marketing model (1992, Brownlie, D. \& Saren, M.). The effectiveness of subcomponents, like public relations, distribution channels, etc. are hard to be measured by quantitative scales. That leads us to collect marketing experts' judgments to understand the relationships between the components to perceive the whole model.

\section{The Concept of Marketing Mix}

4 P's is the basic issue in marketing, which attempts to avow the formulation of reaching to the market. It should be assumed as a prescription and the exact formulation will provide the best marketing performance to the company. The term, marketing mix, is first pronounced by Professor Neil Borden of Harvard Business School in 1964 and defined as "a related group of activities designated to influence

${ }^{*}$ Corresponding author 
buyer behavior". Since then probably it has become the most widely used term in marketing literature. (Knillans, G., 2008).

Regarding to the term $4 \mathrm{P}$, it is clear that, a marketing mix has 4 elements as below:

$$
\begin{array}{ll}
\text { - } & \text { Product } \\
\text { - } & \text { Price } \\
\text { - } & \text { Place (Distribution) } \\
\hline & \text { Promotion }
\end{array}
$$

From 1964 till 2000s, many new Ps are offered to be added to the marketing mix. One example is transforming the term 4P into 6P by including "People" and "Planning" (Knillans, G., 2008). Even though there exists, some other attempts to expand $4 \mathrm{P}$, the marketing mix concept still stays the same. The general use for marketing mix is still as $4 \mathrm{P}$.

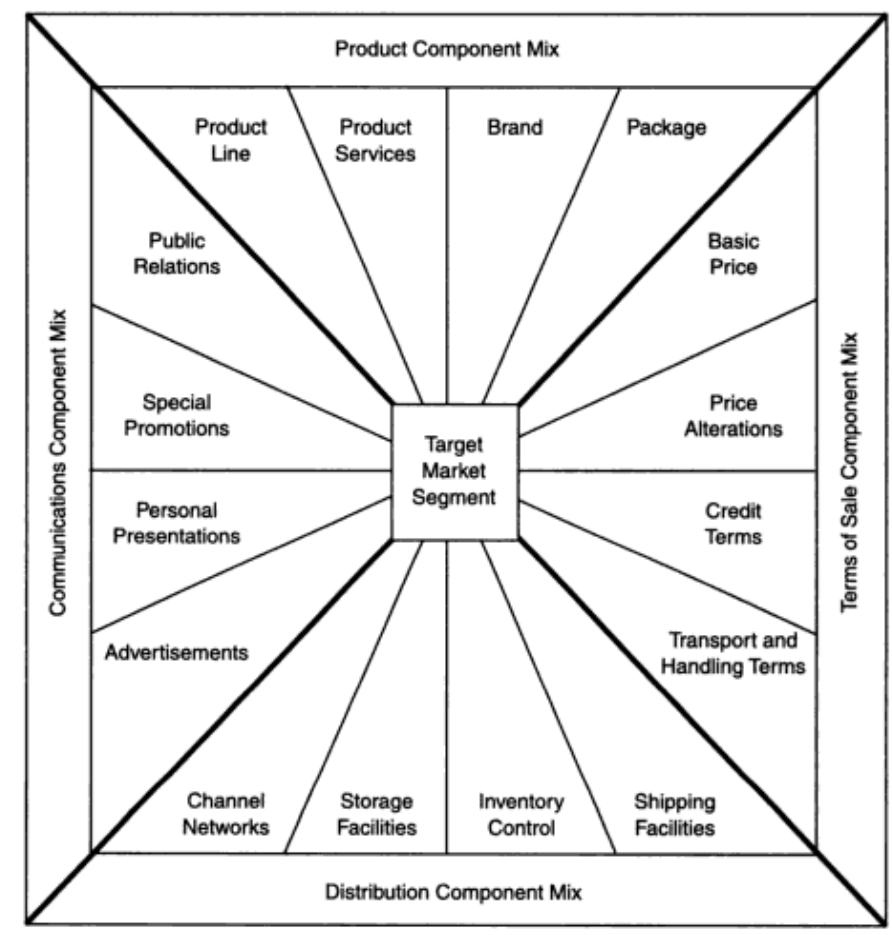

Figure 1. Model of the Customer Market offering dimensions of the Marketing Mix (Lipson, et al.)

Marketing mix development for target market process involves four important steps:

1. Division of the marketing mix into four component-mixes: the product mix, the terms of sale mix, distribution mix and communications mix.

2. Generation of the each component-mixes by assessing the possible dimensions in order to define the contents of each marketing mix.

3. Combination of the four component mixes to generate the integrated marketing mix.

4. Implementation of the marketing mix to the real market conditions. 
The performance of the marketing mix is possible to be measured by market share and profitability (1992, Brownlie, D\&Saren,L.). However, this requires the implementation of a prepared marketing mix. In the planning process, the numerical evaluation of marketing mix alternatives, will help the company to choose the best marketing mix through the alternatives.

Although, there have been some attempts to compute the optimum marketing mix, there is not an integrated model covering all the components and subcomponent. Optimization of marketing mix, is still a non solved considerable marketing problem (1992, Brownlie, D. \& Saren, M.).

Even though the traditional marketing science, approves the four components of the marketing mix as distinct concepts from each other, the four components and their subcomponents are highly interrelated (2002, Constantinides, E.). This paper will investigate the relationships between marketing mix components and calculate the rankings of the subcomponents. The weights found from the Analytic Network Process method will be benefited in the marketing mix generation process.

\section{Analytic Network Process}

Analytic Network process, is a decision making tool used in complex problems. It involves all kinds of relationship, dependency and feedback in the model and draws a systematical figure of the decision making problem. ANP is the more general form of Analytic Hierarchy process, which generates feasible solutions to hierarchical kind of decision problems.

Using pairwise comparisons, all kinds of subcomponents are being evaluated through ANP. There is a 1-9 scale which is also developed by Thomas Saaty and the pairwise comparisons are measured through this scale (Saaty, T., 2005).

ANP consists of five main steps:

1. Performing pairwise comparisons on the elements of the model.

2. Generating unweighted super matrix by putting the relative importance weights (eigenvectors), calculated from pairwise comparison matrices, within the super matrix.

3. Performing pairwise comparisons on the clusters.

4. Generating the weighted super matrix by weighting the blocks of the unweighted super matrix, by the corresponding priorities of the clusters so that it can be column stochastic.

5. Generating the super matrix by raising the weighted super matrix to the power $2 \mathrm{k}+1$, where $\mathrm{k}$ denotes an arbitrary large number, until the weights converge and stays constant (Saaty, T., 2005).

Analytic Network process is used many kind of decision making and priority setting problems. In the literature examples to the application of ANP are; supplier selection (Ming-Lang., T. et al., 2009 and Gencer, C., Gurpinar, D., 2007), project selection (L.M., A. Presley, 2002,.., L.M. Meade, J. Sarkis, 1999 and Mohanty, R.P., Agarwal, R., 2005.), SWOT analysis (Yüksel, I., Dagdeviren, M. 2007) and operation selection. It is also combined with other types of analytical models to provide better results. Examples to the integrated models are fuzzy analytic network process (2007, Ayağ, Z., Özdemir, R.G), ANP integrated goal programming ( Lee, J.W., Kim, S.H., 2001) and ANP based artificial neural networks (Yazgan, H.R. et al., 2009).

As stated in the introduction part, marketing mix consists of interrelated subcomponents that should be integrated to each other. The best composition of marketing mix will enable the increment of customer satisfaction which leads to financial success (2009, Chen, H., Green, R.D.). Analytic Network process is utilized in this paper for understanding the complex relationship between marketing mix components. The 
structure and logic of ANP, which allows utilizing expert judgments in the decision making process, makes it suitable for the problem.

\section{Marketing Mix Analysis using ANP}

Marketing mix has four main components in our model. Besides; price, promotion, place and product decisions are complex judgements which are composed of different and interrelated sub components. In the marketing mix preparation process, all the sub components and relations should be taken into consideration. Table 1 presents the marketing mix (4P) elements and their subcomponents.

Table 1. Elements of Marketing Mix

\begin{tabular}{|l|l|l|l|}
\hline Product & Place & Price & Promotion \\
\hline Product Line & Channel Networks & Basic Price & Public Relations \\
\hline Product Services & Storage Facilities & Price Alterations & Special Promotions \\
\hline Brand & Inventory Control & Credit Terms & Personal Presentations \\
\hline Package & Shipping Facilities & Transport and Handling Terms & Advertisements \\
\hline
\end{tabular}

Table 2. Combined Relationship Matrix

\begin{tabular}{|c|c|c|c|c|c|c|c|c|c|c|c|c|c|c|c|c|c|}
\hline \multirow{2}{*}{\multicolumn{2}{|c|}{$\begin{array}{l}\text { RELANTIONSHIPS } \\
\text { MATRIX }\end{array}$}} & \multicolumn{4}{|c|}{ Product } & \multicolumn{4}{|c|}{ Place } & \multicolumn{4}{|c|}{ Price } & \multicolumn{4}{|c|}{ Promotion } \\
\hline & & \begin{tabular}{|l|}
$\begin{array}{l}\text { Product } \\
\text { Line }\end{array}$ \\
\end{tabular} & $\begin{array}{l}\text { Product } \\
\text { Services }\end{array}$ & Brand & Package & \begin{tabular}{|l} 
Channel \\
Networks
\end{tabular} & \begin{tabular}{|l|} 
Storage \\
Facilities
\end{tabular} & $\begin{array}{l}\text { Inventory } \\
\text { Control }\end{array}$ & $\begin{array}{l}\text { Shipping } \\
\text { Facilities }\end{array}$ & $\begin{array}{l}\text { Basic } \\
\text { Price }\end{array}$ & $\mid \begin{array}{l}\text { Price } \\
\text { Alterations }\end{array}$ & \begin{tabular}{|l} 
Credit \\
Terms
\end{tabular} & \begin{tabular}{|l|} 
Transport \\
and \\
Handling \\
Terms
\end{tabular} & \begin{tabular}{|l|} 
Public \\
Relations
\end{tabular} & $\begin{array}{l}\text { Special } \\
\text { Promotio } \\
\text { ns }\end{array}$ & \begin{tabular}{|l|} 
Personal \\
Presenta \\
tions
\end{tabular} & $\begin{array}{l}\text { Advertise } \\
\text { ments }\end{array}$ \\
\hline \multirow{4}{*}{ 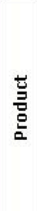 } & \begin{tabular}{|l|} 
Product \\
Line
\end{tabular} & & + & + & + & + & + & + & + & + & + & + & + & + & + & + & + \\
\hline & \begin{tabular}{|l|} 
Product \\
Services
\end{tabular} & + & & & & & & & & & + & & & & & & \\
\hline & Brand & + & + & & + & & & & & & & & & + & & & \\
\hline & Package & & & & & & + & & + & + & & & + & + & & & \\
\hline \multirow{4}{*}{$\frac{\mathscr{\pi}}{2}$} & $\begin{array}{l}\text { Channel } \\
\text { Networks }\end{array}$ & + & + & & & & + & + & + & + & + & & + & + & & + & + \\
\hline & $\begin{array}{l}\text { storage } \\
\text { Facilities }\end{array}$ & + & + & & & & & + & + & + & + & & + & & & & \\
\hline & $\begin{array}{l}\text { Inventory } \\
\text { Control }\end{array}$ & & & & & & + & & & & + & & & & & & \\
\hline & $\begin{array}{l}\text { Shipping } \\
\text { Facilities } \\
\end{array}$ & & & & + & + & + & + & & + & + & & + & & & & \\
\hline \multirow{4}{*}{ 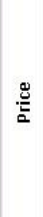 } & Basic Price & + & + & + & + & & & & & & & & & + & & & + \\
\hline & \begin{tabular}{|l|} 
Price \\
Alterations
\end{tabular} & & & & & & & & & & & & & & & & \\
\hline & $\begin{array}{l}\text { Credit } \\
\text { Terms }\end{array}$ & & & & & & & & & & & & + & & & & \\
\hline & $\begin{array}{l}\text { Transport } \\
\text { and }\end{array}$ & & + & & + & + & & & & & & & & & & & \\
\hline \multirow{4}{*}{ 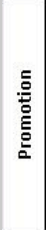 } & \begin{tabular}{|l}
$\begin{array}{l}\text { Public } \\
\text { Relations }\end{array}$ \\
\end{tabular} & & & + & + & & & & & + & + & & & & + & + & + \\
\hline & \begin{tabular}{|l|} 
Special \\
Promotions
\end{tabular} & & & & + & & & & & & + & + & + & & & + & + \\
\hline & \begin{tabular}{|l|} 
Personal \\
Presentatio
\end{tabular} & & & & & & & & & & + & + & & & & & \\
\hline & $\begin{array}{l}\text { Advertisem } \\
\text { ents }\end{array}$ & & & & & & & & & + & + & + & & + & & & \\
\hline
\end{tabular}

After the relationships are identified, the model is computerized using Superdecisions 2.0.6. The combined model is demonstrated in Figure 2. As seen in the figure, there are feedbacks through all the 
clusters and interdependencies within all the clusters. As an example, there exist a feed back through brand and product line, which are both in the same cluster; Product. Another example will be the feedback between the Package node of Product Cluster and Transport and Handling Terms node of Place cluster. However there is one way interaction between price alterations and shipping facilities.

The bigger picture of the model will be discovered using Table 2 and Figure 2 together.

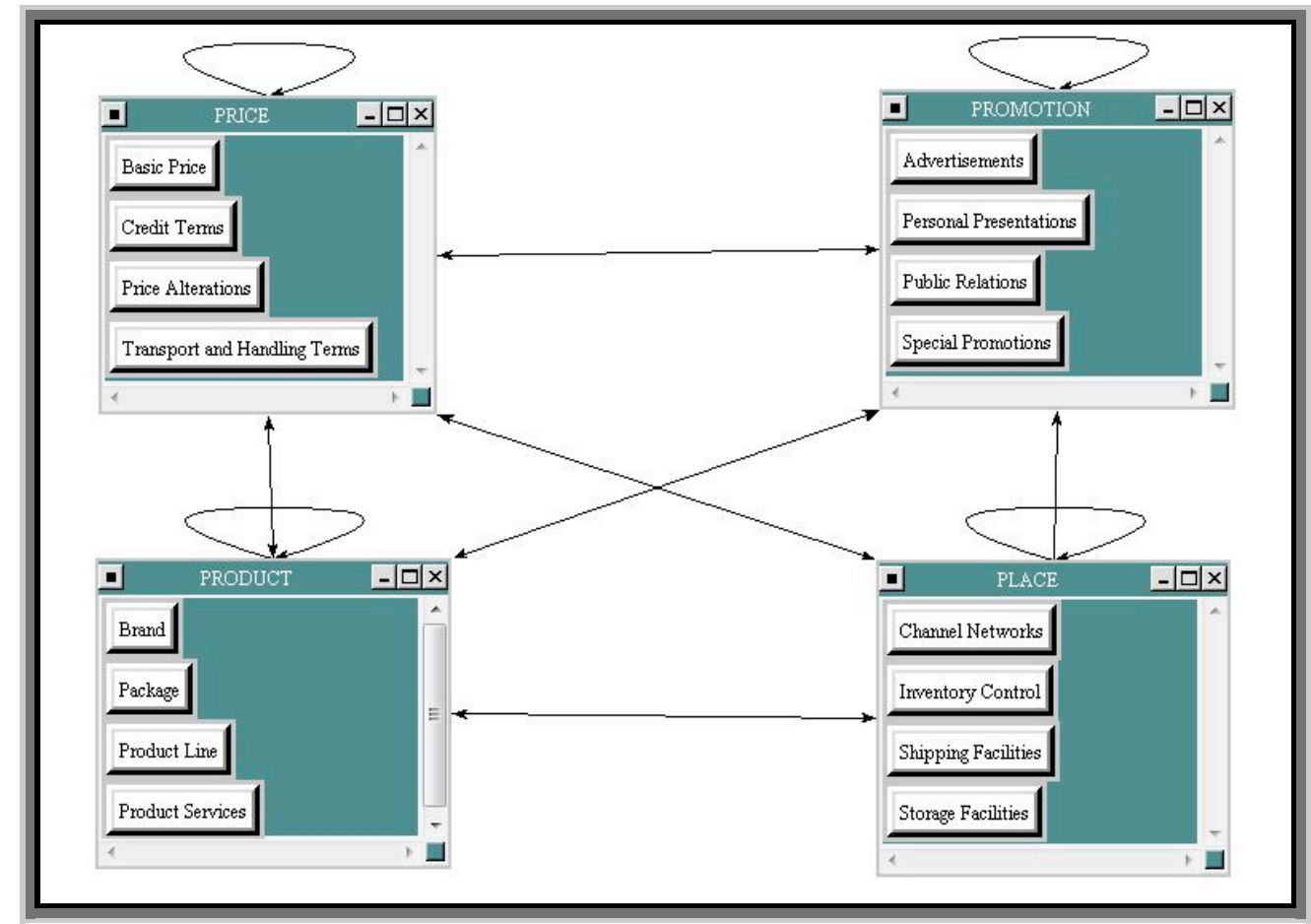

Figure 2. The Marketing Mix ANP Model

The pairwise comparisons are committed via Superdecisions software. In pairwise comparisons Saaty Scale is employed. If one or two criteria are modeled to affect a criterion, the relative importance of them with respect to the criterion is assessed. As an example, both inventory control and shipping facilities are defined as affecting storage facilities. As their influence is considered, shipping facilities is assessed as slightly more effecting storage facilities than inventory control.

After the formation of unweighted, weighted and limit supermatrices, the final priorities of the nodes are found. The priorities are submitted in descending order. The most important factor is Public Relations, which is found to be the most important element of Marketing Mix. Public relations becomes more and more vital, to create value and increase brand equity. Companies are more concerned about the ethical issues and with the increasing prevalence of media, customers are more aware of the companys' operations.

The second effective factor is price alterations, which proves the importance of price in purchasing behavior. Although there is no price concern in some niche markets, it is still an important part of purchasing decisions. Advertisement, product line and channel networks are the consequent three subcomponents. Advertisement is in the promotion part and creates brand and product awareness. Product line is the collection of the product, offered by the company and it gives the bundle of services offered by the company the customer. 
Table 3. The weights of Marketing Mix Subcomponents

\begin{tabular}{|l|r|c|}
\hline MARKETING MIX ELEMENT & $\begin{array}{l}\text { Normalized } \\
\text { By Cluster }\end{array}$ & Limiting \\
\hline Public Relations & 0.146605 & 0.49516 \\
\hline Price Alterations & 0.113223 & 0.40441 \\
\hline Advertisements & 0.117963 & 0.39842 \\
\hline Product Line & 0.112876 & 0.38446 \\
\hline Channel Networks & 0.047210 & 0.36216 \\
\hline Basic Price & 0.099848 & 0.35664 \\
\hline Storage Facilities & 0.044418 & 0.34075 \\
\hline Brand & 0.078083 & 0.26595 \\
\hline Shipping Facilities & 0.029737 & 0.22812 \\
\hline Transport and Handling Terms & 0.055228 & 0.19726 \\
\hline Package & 0.056242 & 0.19156 \\
\hline Product Services & 0.046397 & 0.15803 \\
\hline Special Promotions & 0.020907 & 0.07061 \\
\hline Inventory Control & 0.008990 & 0.06897 \\
\hline Credit Terms & 0.011672 & 0.04169 \\
\hline Personal Presentations & 0.010600 & 0.03580 \\
\hline
\end{tabular}

Basic price, storage facilities, brand, shipping facilities, transport and handling terms, package, product services, special promotions, inventory control, credit terms and personal presentations are the other subcomponents affecting the marketing mix success in descending order. The least affectionate one is personal presentations which may be important in Business to business (B2B) markets. However if the customer is an individual and the target market is quite extensive, it does not contribute much for the advantage of the company.

Table 3 serves the final weights of the Marketing Mix Subcomponents. Second column, stands for the weights normalized by cluster and the third column shows the limiting values of the subcomponents.

\section{Results}

Marketing mix optimization is a non solved problem and needs to be worked on. Therefore, in this paper, the subcomponents or the marketing mix is analyzed. First, the relationships between the subcomponents are defined and second the pairwise comparisons are performed via 1-9 scale. After formations of the unweighted, weighted and limit super matrices, the weights of the subcomponents are found.

The results of the ANP model are visualized through a pie chart in Figure 3. Public relations, is found to be the most important component as stated in marketing mix analysis part. Three components; price alterations, advertisements and product line are in the second order of importance. The distribution of the components marks the increasing importance of promotion. Especially in the FMCG sector, the image 
and style of the product about the forestall the product characteristics. The weights of marketing mix components, found through ANP, will be benefited in the optimization of Marketing Mix.

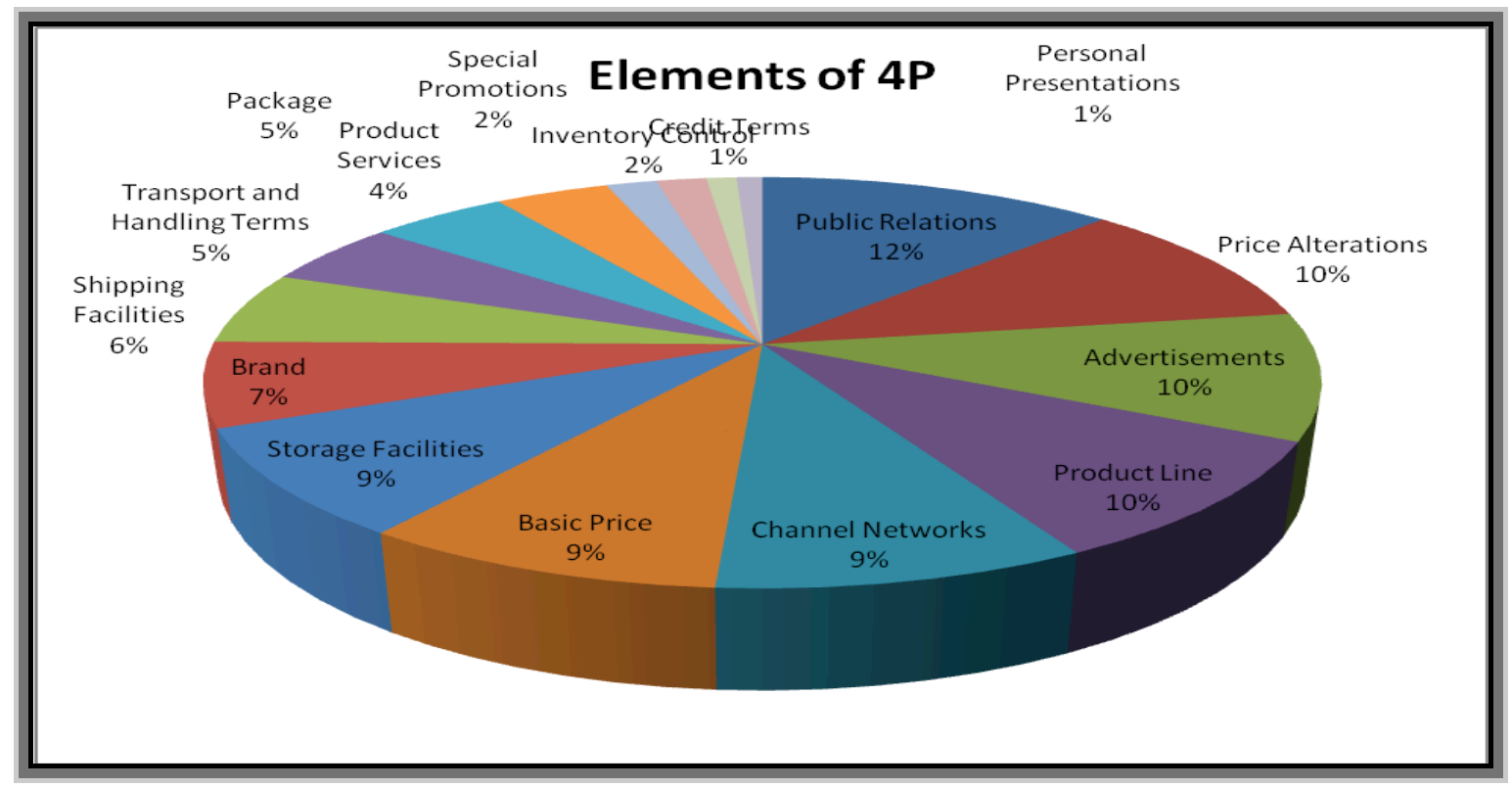

Figure 3. Pie chart of Marketing Mix Components

\section{REFERENCES}

Ayağ, Z. \& Özdemir, R.G., (2007). An Intelligent Approach to ERP software Selection Through Fuzzy ANP. International Journal of Production Research, 45(10), 2169-2194.

Brownlie, Douglas \& Saren, Michael, (1992). The Four Ps of the Marketing Concept: Prescriptive, Polemical, Permanent and Problematical. European Journal of Marketing.

Chen, H. \& Green, R.D., (2009). Marketing Mix and Branding: Competitive Hypermarket strategies. International Journal of Management and Marketing Research, 2(1), 17-34.

Constantinides, E., (2002). The 4S Web-Marketing Mix model. Electronic Commerce Research and Applications, 1(1), 57-76

Gencer, C., \& Gurpinar, D., (2007). Analytic network process in supplier selection: a case study in an electronic firm. Applied Mathematical Modeling, 31(11), 2475-2486.

Knillans, Geri., (2008). Revising the Marketing Mix. U.S. Business Rewiev. 
Lipson, Harry A. \& Reynolds, Fred D. (1970). The Concept of the Marketing Mix: Its Development, Uses, and Applications. MSU Business Topics.

Lee, J.W., \& Kim, S.H.(2001). Using Analytic Network Process and Goal Programming for Interdependent Information System Project Selection. Computers \& Operations Research, 27(4), 367382.

L.M. Meade, \& J. Sarkis, (1999). Analyzing organizational project alternatives for agile manufacturing processes - an analytical network approach. International Journal of Production Research, 37(2), 241261.

L.M. Meade, A. (2002). Presley, R and D project selection using the analytic network process. IEEE Transactions on Engineering Management, 49(1), 59-66.

Ming-Lang., T., Chiang, J.H. \& Lan, L. W. , (2009). Selection of optimal supplier in supply chain management strategy with analytic network process and choquet integral. Computers \& Industrial Engineering, 57(1), 330-340.

Mohanty, R.P., Agarwal, R., Choudhury, A.K., \& Tiwari, M.K. (2005). A fuzzy ANP-based approach to R\&D project selection: a case study. International Journal of Production Research, 43(1), 5199-5216.

Saaty, Thomas L., (2005). Theory and applications of the analytic network process : decision making with benefits, opportunities, costs, and risks. WS publications, Pittsburg.

Yüksel, I.,\& Dagdeviren, M. (2007). Using the analytic network process (ANP) in a SWOT analysis-A case study for a textile firm. Information Sciences, 177(1), 3364-3382.

Yazgan, H.R., Boran,S., \& Göztepe, K., (2009). An ERP Software Selection Process with using artificial neural network based on analytic network process. Expert Systems with Applications, 36(1), 9222. 